Formatif: Jurnal Ilmiah Pendidikan MIPA

Vol. 9, No. 2, Juni 2019, pp. 91-100

p-ISSN: 2088-351X

e-ISSN: $2502-5457$

DOI: http://dx.doi.org/10.30998/formatif.v9i2.3089

\title{
Development of Domino Card as Math Learning Media to Train Students' Conceptual Understanding
}

\section{Pengembangan Kartu Domino sebagai Media Pembelajaran Matematika untuk Melatih Pemahaman Konsep Siswa}

\author{
Arief Aulia Rahman (*) \\ STKIP Bina Bangsa Meulaboh, Jl. Meulaboh-Tapaktuan, Peunaga Cut Ujong, Kec \\ Meureubo, Kab Aceh Barat. 23681 \\ Yuli Amalia \\ STKIP Bina Bangsa Meulaboh, Jl. Meulaboh-Tapaktuan, Peunaga Cut Ujong, Kec \\ Meureubo, Kab Aceh Barat. 23681
}

\begin{abstract}
Received: December 16, 2018 This study aims to describe the validity, practicality and effectiveness of Revised: March 23, 2019 domino card media that will be developed to train students' understanding Accepted: March 29,2019 of concepts in learning mathematics, the instruments used are tests, questionnaires and interview sheets. The research subjects were grade VII of Junior High School at Meulaboh. This research was carried out through two stages, namely the first stage of developing domino card media using the Four-D model, and the second stage testing the domino card media developed to see its effectiveness. From the results of the trial obtained: 1) domino card media developed valid with a value of 77.5 good categories, 2) the practicality of domino cards seen from student response questionnaires with a value of $88.1 \%$ good category. And c) the effectiveness of domino card media in terms of student learning classical completeness, namely $72.7 \%$ is complete.

Keywords: Domino Card, Four-D Model, Understanding of Concepts
\end{abstract}

(*) Corresponding Author: $\quad$ sirariefaulia@gmail.com, Hp. 082364783000

How to Cite: Rahman, A. A. \& Amalia, Y. (2019). Development of domino card as math learning media to train students' conceptual understanding. Formatif: Jurnal Ilmiah Pendidikan MIPA, 9 (2): 91-100. http://dx.doi.org/10.30998/formatif.v9i2.3089

\section{PENDAHULUAN}

Proses belajar matematika masih menggunakan cara-cara klasik dan abstrak dalam membantu siswa untuk memahami konsep dasar matematika seperti dengan menuliskan materi di papan tulis lalu memberi contoh dan latihan. Kemudian masih banyak guru yang belum sepenuhnya menggunakan media pembelajaran pada saat pengajaran matematika. Cara Mengajar yang bersifat abstrak dan klasik inilah yang mengakibatkan siswa merasa bosan serta kesulitan dalam memahami materi pelajaran (Budiono, 2018; Supardi et al, 2012), bahkan tidak mampu menyelesaikan persoalanpersoalan matematika yang diberikan (Astuti et al, 2019).

Berkaitan dengan permasalahan di atas, maka guru berperan penting dalam memahami karakter dan kemampuan siswa (Prasetyo \& Prihatnani, 2018). Hal ini ditujukan agar guru dapat merencanakan kegiatan pembelajaran dengan baik. Selain itu, perlu dikaji dan dikembangkan komponen-komponen yang terlibat dalam sistem 
Formatif: Jurnal Ilmiah Pendidikan MIPA

Vol. 9, No. 2, Juni 2019, pp. 91-100

p-ISSN: 2088-351X

e-ISSN: 2502-5457

DOI: http://dx.doi.org/10.30998/formatif.v9i2.3089

pembelajaran. Salah satunya adalah dengan mengkaji dan mengembangkan media pembelajaran yang sesuai dengan materi yang akan diajarkan (Harsono \& Prihatnani, 2018). Hal ini dikaji sebagai usaha untuk membantu siswa dalam memahami pelajaran matematika.

Penggunaan media pembelajaran yang sesuai materi pembelajaran dapat dijadikan sebagai alat bantu guru dalam menyampaikan atau mengomunikasikan pengetahuan yang akan disampaikan kepada siswa (Wijayanti et al, 2018). Media pembelajaran harus sesuai dengan materi pembelajaran karena setiap materi pelajaran memiliki kekhasan dan kekompleksan masing-masing (Prihanto \& Yunianta, 2018). Kemudian, dengan ketersediaan media pembelajaran matematika, membuat siswa tidak lagi hanya mendengar dan mencatat saja tetapi juga lebih aktif, kreatif dalam berpikir, dan termotivasi (Barnawi \& Arifin, 2017; Handika, 2012; Sanjaya, 2011). Media pembelajaran adalah segala alat fisik yang dapat menyajikan pesan, menyampaikan pesan, serta merangsang siswa untuk belajar (Sutiarso dkk, 2018).

Berdasarkan hasil wawancara yang dilakukan dengan guru mata pelajaran matematika kelas VII SMP Negeri 1 Meulaboh, diperoleh informasi bahwa cara mengajar yang dilakukan guru sudah baik. Namun, masih sedikit klasik karena semua kegiatan pembelajaran tidak sepenuhnya menggunakan media pembelajaran. Selain itu, hasil wawancara dari beberapa siswa kelas VII SMP Negeri 1 Meulaboh, diperoleh bahwa materi sudut adalah salah satu materi yang masih dianggap sukar. Sebagian siswa tersebut sulit dalam menentukan jenis-jenis sudut dan memperkirakan besar sudut berdasarkan jenis-jenis sudut yang mereka ketahui. Hal ini terbukti ketika peneliti menanyakan materi terkait jenis-jenis sudut dan besar sudut dengan mengaitkan pada aktivitas sehari-hari, jawaban mereka menggambarkan bahwa mereka belum dapat memperkirakan dan mengategorikan dari suatu yang konkret ke yang abstrak. Inilah yang terjadi jika pemahaman siswa kurang dan belum berada pada stadium operasional formal.

Menurut Sagala (2010) stadium operasional formal dimulai pada anak usia 12 tahun yaitu lebih kurang anak pada usia sekolah menengah pertama. Pada stadium ini siswa mampu berpikir secara simbolis dan dapat memahami tanpa memerlukan objek yang konkret atau bahkan objek visual. Hasil yang didapatkan peneliti di lapangan berbanding terbalik seperti teori, dan dapat diketahui bahwa mereka masih berada pada tahap transisi ke stadium operasional formal dalam memahami materi sudut.

Solusi yang dipikirkan peneliti untuk membantu pemahaman materi sudut pada siswa yaitu dengan mencoba menggunakan dan mengembangkan media pembelajaran berbasis visual serta permainan berupa kartu domino. Menurut Hestuaji dkk (2013) permainan kartu domino dapat membantu siswa dalam latihan mengasah kemampuan memecahkan berbagai masalah yang berkaitan dengan kehidupan sehari-hari dan logika.

Media pembelajaran ini dinamakan kartu domino sudut. Kartu domino adalah salah satu media yang dapat membantu siswa dalam memahami materi, dapat meningkatkan hasil belajar, dan dapat merangsang keaktifan siswa dalam kegiatan belajar. Hal ini didukung oleh penelitian yang telah dilakukan oleh Hestuaji dkk (2013) dengan hasil bahwa penggunaan media kartu domino dapat meningkatkan pemahaman, meningkatkan hasil belajar siswa, dan dapat menarik minat siswa dalam pembelajaran matematika. Selain itu, kartu domino sudut juga sesuai dengan karakteristik siswa usia SMP yang masih senang bermain, bergerak, dan bekerja dalam kelompok. Media pembelajaran ini dipenuhi dengan niat untuk menciptakan harapan agar kondisi pembelajaran matematika terkesan menyenangkan dan tidak lagi menegangkan ataupun sulit untuk dipahami. 


\section{Formatif: Jurnal Ilmiah Pendidikan MIPA}

Vol. 9, No. 2, Juni 2019, pp. 91-100

p-ISSN: 2088-351X

e-ISSN: 2502-5457

DOI: http://dx.doi.org/10.30998/formatif.v9i2.3089

\section{METODE}

Penelitian ini merupakan penelitian research \& development di mana pengembangan media pembelajaran menggunakan model penelitian dan pengembangan 4-D (define, design, develop, dan disseminate) dan telah dimodifikasi menjadi 3-D yaitu define, design, dan develop (Rahman, 2017). Subjek penelitian ini adalah kelas VII-2 SMP Negeri 1 Meulaboh sebagai sasaran pengguna produk yang dipilih secara simple random sampling. Media kartu domino terlebih dahulu akan divalidasi isi oleh dua validator pakar, kemudian dilakukan uji coba media yang bertujuan untuk memperoleh data kepraktisan dan keefektifan media. Sehingga, perbaikan-perbaikan berdasarkan saran/pendapat pakar dan hasil uji coba media di kelas penelitian menghasilkan produk final yang layak digunakan dalam pembelajaran. Media pembelajaran tersebut diujicobakan di sekolah untuk melihat kepraktisan media pembelajaran yang akan dirancang berdasarkan respons siswa terhadap media pembelajaran dan keefektifan media pembelajaran berdasarkan hasil proses jawaban siswa yang dibuat untuk menyelesaikan soal-soal materi sudut.

Instrumen yang digunakan dalam penelitian ini adalah tes pemahaman konsep, angket respons siswa, serta lembar wawancara terstruktur yang digunakan bila peneliti atau pengumpul data telah mengetahui dengan pasti tentang informasi apa yang akan diperoleh. Oleh karena itu, dalam melakukan wawancara, pengumpul data telah menyiapkan instrumen penelitian berupa pertanyaan-pertanyaan tertulis dengan alternatif jawaban yang akan digunakan sebagai acuan dalam perbaikan media kartu domino.

\section{HASIL DAN PEMBAHASAN}

\section{Hasil}

Rancangan kartu domino ini dibuat sebanyak 24 kartu. Adapun salah satu hasil rancangan awal media pembelajaran kartu domino sudut yang dikembangkan peneliti sebagai berikut.

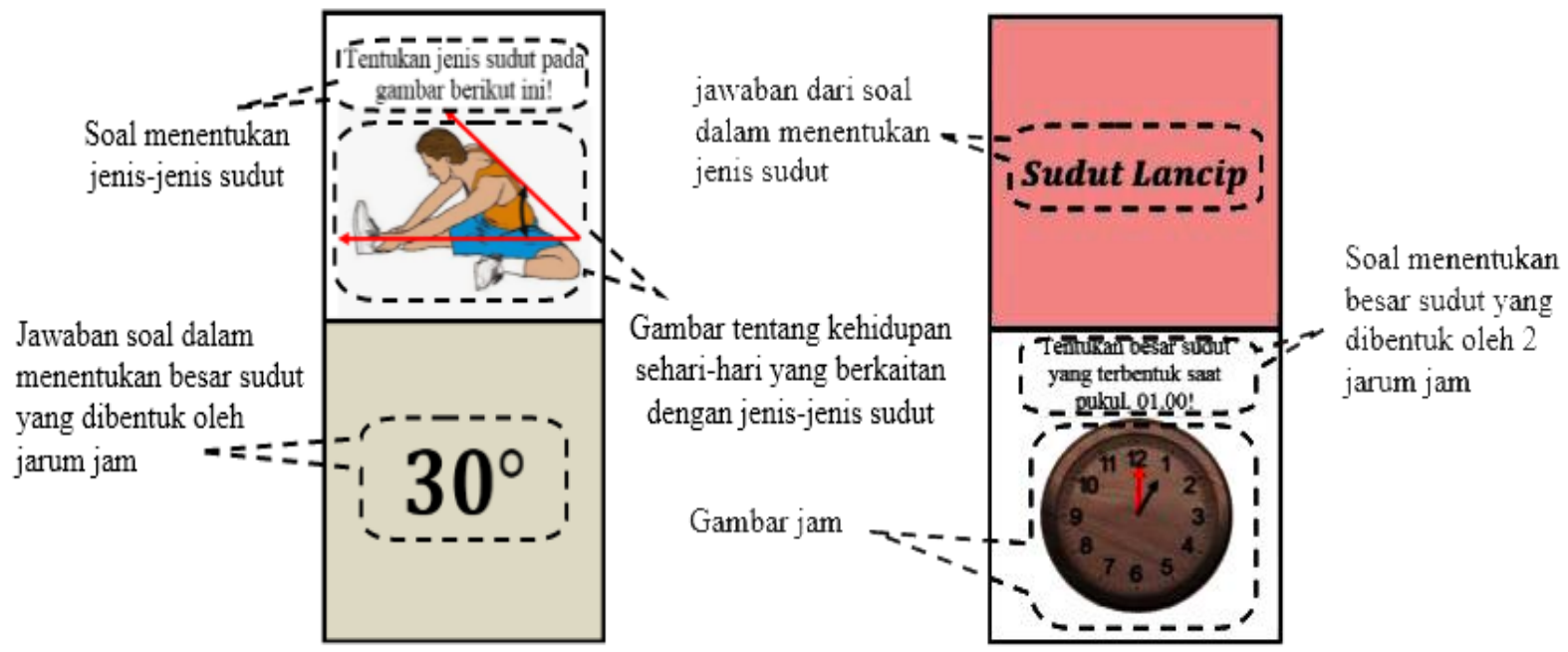

Gambar 1. Rancangan Awal Kartu Domino Sudut 


\section{Formatif: Jurnal Ilmiah Pendidikan MIPA}

Vol. 9, No. 2, Juni 2019, pp. 91-100

p-ISSN: 2088-351X

e-ISSN: 2502-5457

DOI: http://dx.doi.org/10.30998/formatif.v9i2.3089

Kegiatan awal yang dilakukan adalah penilaian para ahli (expert appraisal) dan uji coba rancangan produk (developmental testing) pada uji coba subjek penelitian.

\section{a. Penilaian Ahli (Expert Appraisal)}

Sebelum media pembelajaran dan instrumen digunakan dalam kegiatan pembelajaran, peneliti terlebih dahulu melakukan pemeriksaan ulang kepada para ahli (validator) untuk memperoleh media pembelajaran dan instrumen penelitian yang valid. Instrumen penelitian yang divalidkan yaitu lembar angket respons siswa, lembar tes hasil belajar, dan media kartu domino. Peneliti memilih dua validator yang berkompeten dalam hal materi dan media. Penilaian ahli pada media pembelajaran meliputi validasi isi. Penilaian umum dari validasi media pembelajaran adalah media pembelajaran ini baik dan dapat digunakan dengan sedikit revisi. Berdasarkan penilaian umum yang diberikan validator, peneliti pertimbangkan untuk merevisi I (draf II) media pembelajaran. Revisi yang dilakukan peneliti adalah media pembelajaran disesuaikan kembali dengan materi sudut dan menambahkan simbol $\alpha, \beta, \gamma$, dan $\theta$. Selanjutnya peneliti juga lebih memperjelas soal untuk mencegah timbulnya jawaban ganda. Mengenai hasil validasi media pembelajaran, lebih jelasnya akan dijelaskan pada analisis data kevalidan media pembelajaran. Berikut merupakan gambar hasil sebelum dan sesudah revisi I media pembelajaran:

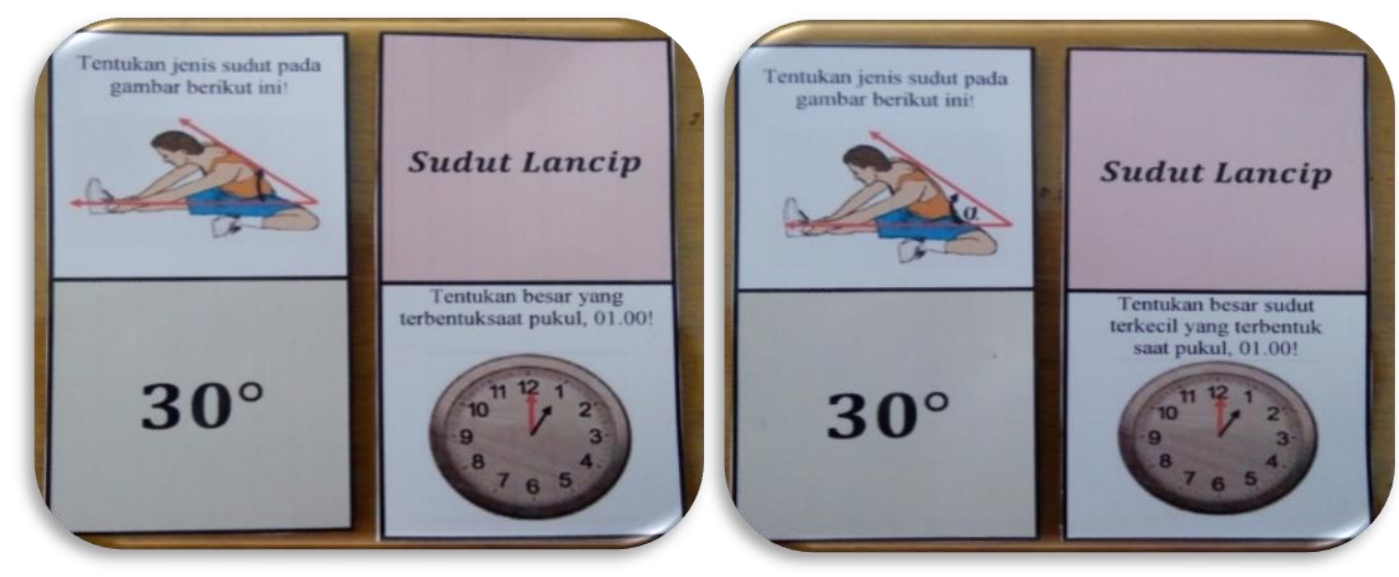

Gambar 2. Media Sebelum dan sesudah Revisi I

Rencana Pelaksanaan Pembelajaran (RPP) yang telah disusun peneliti divalidasi terlebih dahulu oleh validator. Hasil penilaian umum dari validasi RPP yaitu RPP yang disusun sudah baik dan dapat digunakan dengan sedikit revisi. Komentar dan saran secara lisan yang diberikan adalah RPP harus sesuai dengan aturan Kurikulum 2013 dan tampilkan gambar media pembelajaran pada kegiatan pembelajaran. Selain itu komentar dan saran secara tulisan adalah setiap Kompetensi Dasar (KD) harus memuat semua capaian kompetensi, setiap KD mempunyai minimal satu indikator capaian kompetensi, tujuan dan model sebaiknya tidak dicantumkan, pada setiap kegiatan sebaiknya menunjukkan/memuat ilustrasi yang akan ditunjukkan.

Angket respons siswa yang dinilai oleh validator memperoleh komentar dan saran berupa angket respons siswa harus disesuaikan dengan tujuan penelitian dan tujuan penggunaan angket. Hasil penilaian umum dari lembar validasi angket respons siswa adalah angket respons siswa yang disusun sudah baik dan dapat digunakan dengan sedikit revisi.

Tes yang disusun peneliti juga turut divalidasi oleh validator. Adapun komentar dan saran perbaikan yang diberikan validator adalah soal tes pemahaman seharusnya 


\section{Formatif: Jurnal Ilmiah Pendidikan MIPA}

Vol. 9, No. 2, Juni 2019, pp. 91-100

p-ISSN: 2088-351X

e-ISSN: 2502-5457

DOI: http://dx.doi.org/10.30998/formatif.v9i2.3089

disesuaikan dengan tujuan dilakukannya tes pemahaman. Penilaian umum yang diberikan oleh validator adalah tes kemampuan pemahaman ini baik dan dapat digunakan dengan sedikit revisi.

b. Uji Coba Produk pada Kelompok Kecil (Developmental Testing)

Uji coba produk pada kelompok kecil dilakukan peneliti di kelas VII-4 SMP Negeri 1 Meulaboh. Uji coba pada kelompok kecil ini melibatkan enam siswa yang dipilih dengan teknik simple random sampling. peneliti dengan sengaja memilih enam orang karena pada satu set kartu domino yang berjumlah 24 kartu dapat dimainkan oleh empat sampai enam orang. Hal ini dilakukan agar kartu domino dapat dibagi secara merata. Peneliti meminta siswa memberikan penilaian terhadap media pembelajaran dengan mengisi angket respons siswa untuk mengetahui praktis atau tidaknya media pembelajaran. Hasil pengisian angket respons siswa dari kelompok kecil disajikan pada tabel 1 .

Tabel 1. Data Hasil Angket Respons Siswa dari Kelompok Kecil

\section{Indikator}

Kemanfaatan dalam penggunaan media

\begin{tabular}{|c|c|}
\hline & $\begin{array}{l}\text { Kemantaatan dalam penggunaan media } \\
\text { pembelajaran (kepuasan, minat, ketertarikan, }\end{array}$ \\
\hline
\end{tabular}

\begin{tabular}{cccccccccccc} 
& NB & NB & NB & NB & NB & NB & NB & NB & NB & NB & NB \\
& 1 & 2 & 4 & 5 & 6 & 7 & 8 & 3 & 9 & 10 & 11 \\
\hline S1 & 4 & 4 & 3 & 4 & 4 & 5 & 3 & 5 & 4 & 4 & 5 \\
S2 & 4 & 4 & 1 & 3 & 5 & 2 & 1 & 5 & 3 & 4 & 2 \\
S3 & 3 & 4 & 5 & 3 & 4 & 2 & 5 & 5 & 3 & 4 & 4 \\
S4 & 5 & 5 & 2 & 3 & 3 & 3 & 3 & 3 & 3 & 3 & 3 \\
S5 & 4 & 4 & 4 & 4 & 4 & 4 & 4 & 4 & 4 & 4 & 4 \\
S6 & 4 & 5 & 4 & 4 & 4 & 5 & 4 & 4 & 4 & 4 & 5 \\
Jumlah & 25 & 26 & 19 & 21 & 24 & 21 & 20 & 26 & 21 & 23 & 23 \\
$\%$ & $83,3 \%$ & $86,7 \%$ & $63,3 \%$ & $70 \%$ & $80 \%$ & $70 \%$ & $66,7 \%$ & $86,7 \%$ & $70 \%$ & $76,7 \%$ & $76,7 \%$ \\
\hline
\end{tabular}

Keterangan:

NB : Nomor Butir

$\%$ : Persentase

Komentar yang diberikan responden pada uji coba kelompok kecil adalah gambar masih kurang dimengerti. Hal ini dikarenakan gambar memiliki arti ganda, maksudnya gambar dapat dikategorikan menjadi dua jenis sudut. Contohnya, gambar yang dimaksudkan untuk menunjukkan jenis sudut siku-siku malah terlihat seperti sudut lancip. Hal ini yang dijadikan sebagai pedoman untuk merevisi media pembelajaran menjadi revisi II.

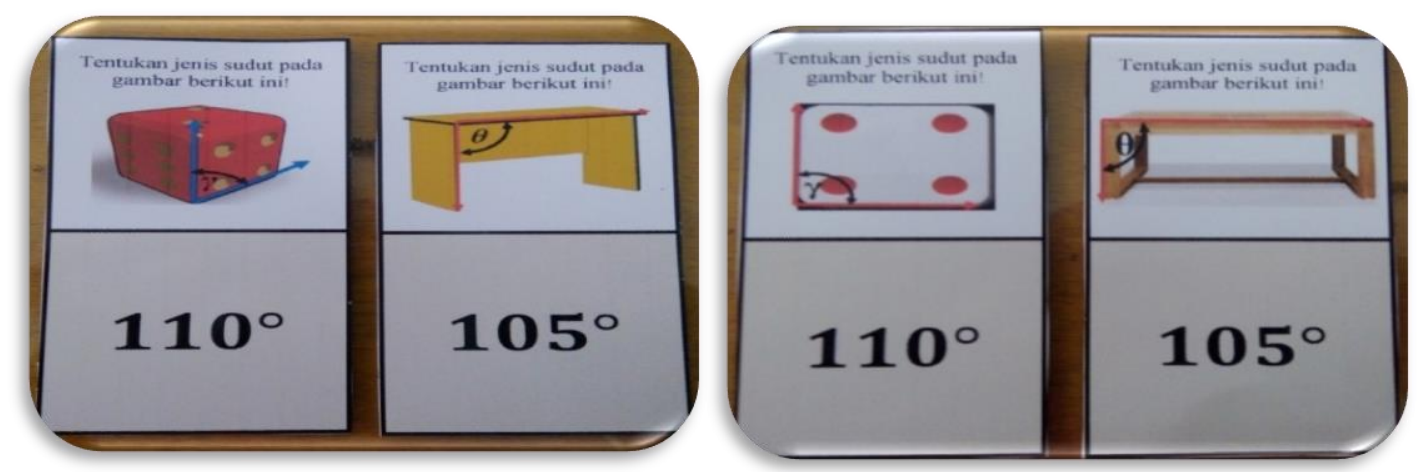

Gambar 3. Media Sebelum dan sesudah Revisi II 


\section{Formatif: Jurnal Ilmiah Pendidikan MIPA}

Vol. 9, No. 2, Juni 2019, pp. 91-100

p-ISSN: 2088-351X

e-ISSN: 2502-5457

DOI: http://dx.doi.org/10.30998/formatif.v9i2.3089

Media pembelajaran yang dikembangkan pada penelitian ini dikatakan layak apabila memenuhi tiga aspek kualitas produk yang meliputi aspek valid, aspek praktis, dan aspek efektif. Media pembelajaran yang telah divalidasi dan diujikan kepada kelompok kecil, kemudian diujikan di kelas penelitian untuk menilai kelayakan media kartu domino dalam memudahkan siswa memahami konsep materi sudut. Berikut adalah hasil analisis kevalidan, kepraktisan, dan keefektifan media kartu domino di kelas penelitian

\section{Analisis Data Kevalidan Media Pembelajaran}

Hasil kevalidan media pembelajaran dapat dilihat dari data hasil validasi yang dilakukan oleh dua validator. Penilaian ahli pada media pembelajaran meliputi validasi aspek isi. Adapun hasil validasi disajikan pada tabel berikut:

Tabel 2. Hasil Analisis Data Validasi Media Pembelajaran pada Aspek Isi

\begin{tabular}{|c|c|c|c|c|c|c|c|}
\hline \multirow[t]{2}{*}{ Indikator } & \multirow{2}{*}{$\begin{array}{l}\text { No. } \\
\text { Butir }\end{array}$} & \multicolumn{2}{|c|}{$\begin{array}{c}\text { Validator } \\
\text { Ke }\end{array}$} & \multirow{2}{*}{$\begin{array}{c}\text { Jumlah } \\
\text { Skor }\end{array}$} & \multirow[t]{2}{*}{$\%$} & \multirow{2}{*}{$\begin{array}{l}\text { Rata- } \\
\text { rata }\end{array}$} & \multirow[t]{2}{*}{ Kriteria } \\
\hline & & 1 & 2 & & & & \\
\hline \multirow{2}{*}{$\begin{array}{l}\text { Kesesuaian media } \\
\text { pembelajaran } \\
\text { dengan kurikulum } \\
\text { yang berlaku }\end{array}$} & 1 & 4 & 4 & 8 & $80 \%$ & & \\
\hline & 2 & 4 & 3 & 7 & $70 \%$ & $75 \%$ & Baik \\
\hline \multirow{2}{*}{$\begin{array}{l}\text { Kesesuaian media } \\
\text { pembelajaran } \\
\text { dengan tujuan } \\
\text { pembelajaran }\end{array}$} & & & & & & & \\
\hline & 4 & 4 & 4 & 8 & $80 \%$ & $80 \%$ & Baik \\
\hline \multirow{4}{*}{$\begin{array}{l}\text { Kesesuaian media } \\
\text { pembelajaran } \\
\text { dengan materi } \\
\text { yang dipelajari }\end{array}$} & 3 & 4 & 3 & 7 & $70 \%$ & & \\
\hline & 5 & 4 & 4 & 8 & $80 \%$ & & \\
\hline & 6 & 4 & 4 & 8 & $80 \%$ & $77,5 \%$ & Baik \\
\hline & 7 & 4 & 3 & 7 & $80 \%$ & & \\
\hline \multicolumn{4}{|c|}{ Rata-rata dari Seluruh Indikator } & & & $77,5 \%$ & Baik \\
\hline
\end{tabular}

Hasil rata-rata dari seluruh indikator pada aspek isi yang dinilai validator sebesar $77,5 \%$, artinya bahwa media pembelajaran pada aspek isi termasuk dalam kriteria baik. Rata-rata total dari hasil validasi media pembelajaran pada aspek konstruksi dan aspek isi sebesar $77,7 \%$, ini berarti media pembelajaran dikriteriakan baik sehingga media pembelajaran dapat dikatakan valid.

\section{Analisis Data Kepraktisan Media Pembelajaran}

Kepraktisan media pembelajaran dalam penelitian ini diperoleh dari hasil angket respons siswa yang dilakukan oleh enam orang siswa kelas VII-4 SMP Negeri 1 Meulaboh (uji coba pada kelompok kecil) dan 22 siswa kelas VII-2 SMP Negeri 1 Meulaboh (uji coba pada subjek penelitian). Berikut merupakan tabel-tabel hasil analisis data angket respons siswa: 
Formatif: Jurnal Ilmiah Pendidikan MIPA

Vol. 9, No. 2, Juni 2019, pp. 91-100

p-ISSN: 2088-351X

e-ISSN: 2502-5457

DOI: http://dx.doi.org/10.30998/formatif.v9i2.3089

Tabel 3. Hasil Analisis Data Angket Respons Siswa pada Kelompok Kecil

\begin{tabular}{lcccc}
\hline Indikator & No. Butir & Persentase (\%) & Rata-rata & Kriteria \\
\hline Kemanfaatan dalam & 1 & $83,3 \%$ & & \\
penggunaan media & 2 & $86,7 \%$ & & \\
pembelajaran & 4 & $63,3 \%$ & & \\
(kepuasan, minat, & 5 & $70 \%$ & $74,2 \%$ & Baik \\
ketertarikan, & 6 & $80 \% \mathrm{~s}$ & & \\
keefektifan) & 7 & $70 \%$ & & \\
Kemudahan & 8 & $66,7 \%$ & & \\
menggunakan & 3 & $86,7 \%$ & & Baik \\
media & 9 & $70 \%$ & $77,5 \%$ & \\
pembelajaran & 10 & $76,7 \%$ & & \\
\multicolumn{5}{c}{ Rata-rata dari Seluruh Indikator } \\
\hline \multicolumn{5}{c}{$76,7 \%$} \\
\hline
\end{tabular}

Hasil analisis data angket respons siswa pada kelompok kecil memperoleh ratarata dari seluruh indikator sebesar 75,8 \%, berarti termasuk pada kriteria baik. Sehingga media pembelajaran dapat dikatakan praktis.

Tabel 4. Hasil Analisis Data Angket Respons Siswa pada Subjek Penelitian

\begin{tabular}{|c|c|c|c|c|}
\hline Indikator & No. Butir & $\begin{array}{l}\text { Persentase } \\
(\%)\end{array}$ & Rata-rata & Kriteria \\
\hline \multirow{7}{*}{$\begin{array}{l}\text { Kemanfaatan } \\
\text { penggunaan } \\
\text { pembelajaran } \\
\text { (kepuasan, } \\
\text { ketertarikan, } \\
\text { keefektifan) }\end{array}$} & 1 & $85,4 \%$ & \multirow{7}{*}{$88,9 \%$} & \multirow{7}{*}{ Baik } \\
\hline & 2 & $94,5 \%$ & & \\
\hline & 4 & $90 \%$ & & \\
\hline & 5 & $90 \%$ & & \\
\hline & 6 & $91 \%$ & & \\
\hline & 7 & $81,8 \%$ & & \\
\hline & 8 & $90 \%$ & & \\
\hline \multirow{3}{*}{$\begin{array}{l}\text { Kemudahan } \\
\text { menggunakan media } \\
\text { pembelajaran }\end{array}$} & 3 & $83,6 \%$ & \multirow{3}{*}{$87,4 \%$} & \multirow{3}{*}{ Baik } \\
\hline & $\begin{array}{c}9 \\
10\end{array}$ & $\begin{array}{l}90 \% \\
88,1 \%\end{array}$ & & \\
\hline & 11 & $88,1 \%$ & & \\
\hline \multicolumn{3}{|c|}{ Rata-rata dari Seluruh Indikator } & $88,1 \%$ & Baik \\
\hline
\end{tabular}

Hasil analisis data angket respons siswa pada subjek penelitian memperoleh ratarata dari seluruh indikator sebesar $88,1 \%$ dan termasuk pada kriteria baik dan dapat dikatakan praktis. Hasil ini menunjukkan media pembelajaran dapat dikatakan praktis dengan persentase masing-masing $75,8 \%$ dan $88,1 \%$ serta keduanya sama-sama dalam kriteria baik.

\section{Analisis Data Keefektifan Media Pembelajaran}

Perolehan hasil analisis data tes kemampuan pemahaman digunakan untuk mengetahui keefektifan media pembelajaran. Adapun hasil analisis datanya disajikan sebagai berikut: 
Formatif: Jurnal Ilmiah Pendidikan MIPA

Vol. 9, No. 2, Juni 2019, pp. 91-100

p-ISSN: 2088-351X

e-ISSN: 2502-5457

DOI: http://dx.doi.org/10.30998/formatif.v9i2.3089

Tabel 5. Hasil Analisis Tes Kemampuan Pemahaman Siswa

\begin{tabular}{lcc}
\hline \multicolumn{1}{c}{ Keterangan } & Jumlah & Persentase (\%) \\
\hline Siswa yang Tuntas & 16 & $72,7 \%$ \\
Siswa yang Tidak Tuntas & 6 & $27,3 \%$ \\
\hline
\end{tabular}

Persentase jumlah siswa yang mencapai ketuntasan termasuk dalam kriteria baik dengan persentase sebesar $72,7 \%$. Hal ini menunjukkan bahwa media pembelajaran yang dikembangkan peneliti dikatakan efektif penggunaannya dalam kegiatan pembelajaran.

\section{Pembahasan}

Pengembangan media pembelajaran kartu domino dilakukan melalui tahap 4-D yang dibatasi menjadi 3-D oleh peneliti. Tahap yang dilakukan adalah tahap define (pendefinisian), design (perancangan), dan develop (pengembangan). Tahap define dimulai dengan wawancara kepada enam orang siswa, lalu didapat empat orang siswa tidak menyukai pelajaran matematika dengan alasan bahwa pelajaran matematika itu sulit untuk dipahami. Ketika peneliti menanyakan terkait materi sudut yaitu jenis-jenis sudut dan besar sudut dengan mengaitkan pada aktivitas atau kehidupan sehari-hari, hasil jawaban mereka menggambarkan belum dapat memperkirakan dan mengategorikan dari suatu yang konkret ke yang abstrak walaupun diketahui bahwa pelajaran tentang sudut telah mereka dapatkan pada saat di sekolah dasar (SD)/madrasah ibtidaiyah (MI). Hal ini membuktikan siswa tersebut masih mengalami tahap transisi dari stadium operasional konkret ke stadium operasional formal.

Tahap design dilakukan dengan menyusun tes, memilih media pembelajaran yang dapat membantu siswa SMP kelas VII dalam memahami materi sudut, memilih format media yang peneliti lihat dari aspek konstruksi, merancang media, dan instrumen penelitian. Dalam satu set media pembelajaran yang dirancang, dibuat sebanyak 24 kartu.

Kartu domino yang dirancang peneliti di dalamnya terdapat gambar tentang kehidupan sehari-hari yang berkaitan dengan jenis-jenis sudut disertai dengan soal menentukan jenis-jenis sudut (sudut tumpul, sudut lancip, sudut siku-siku, sudut lurus, dan sudut refleksi), jawaban dari soal dalam menentukan jenis sudut, gambar jam yang disertai dengan soal menentukan besar sudut yang dibentuk oleh jarum jam pada gambar tersebut, dan terdapat jawaban soal dalam menentukan besar sudut yang dibentuk oleh jarum jam. Hasil dari rancangan awal media merupakan draf I media pembelajaran.

Kelayakan media pembelajaran pada penelitian ini ditinjau dari tiga aspek kualitas produk menurut Nieveen (2007) yaitu valid, praktis, dan efektif. Kevalidan media pembelajaran dapat dilihat dari hasil validasi yang dilakukan validator pada lembar validasi media pembelajaran. Validasi media pada aspek isi terhadap setiap indikator menunjukkan hasil bahwa: 1) Kesesuaian media pembelajaran dengan kurikulum yang berlaku dinilai baik dengan rata-rata persentase $70 \%$,2) Kesesuaian media pembelajaran dengan tujuan pembelajaran dinilai baik dengan rata-rata persentase $80 \%$, 3) Kesesuaian media pembelajaran dengan materi yang dipelajari dinilai baik dengan rata-rata persentase $77,5 \%$. Rata-rata dari seluruh indikator pada aspek isi dinilai baik dengan persentase $77,5 \%$. Dengan demikian, media pembelajaran yang dikembangkan peneliti berdasarkan hasil rata-rata dari seluruh indikator dari validasi aspek konstruksi dan validasi aspek isi diperoleh rata-rata total sebesar 77,7\%, ini berarti media pembelajaran dikategorikan baik sehingga media pembelajaran dapat dikatakan valid.

Produk diujicobakan setelah dilakukan revisi I media pembelajaran. Uji coba dilakukan pada kelompok kecil yang terdiri dari enam orang siswa kelas VII-4 SMP 
Formatif: Jurnal Ilmiah Pendidikan MIPA

Vol. 9, No. 2, Juni 2019, pp. 91-100

p-ISSN: 2088-351X

e-ISSN: 2502-5457

DOI: http://dx.doi.org/10.30998/formatif.v9i2.3089

Negeri 1 Meulaboh untuk mengetahui kepraktisan media pembelajaran dengan memberikan angket respons siswa. Berdasarkan hasil analisis data respons siswa pada uji coba kelompok kecil dari setiap indikator menunjukkan bahwa: 1) Kemanfaatan dalam penggunaan media pembelajaran (kepuasan, minat, ketertarikan, keefektifan) dinilai baik dengan rata-rata persentase $74,2 \%, 2)$ Kemudahan menggunakan media pembelajaran dinilai baik dengan rata-rata persentase $77,5 \%$. Hasil rata-rata dari seluruh indikator angket respons siswa pada uji coba kelompok kecil diperoleh sebesar 75,8\%, sehingga berada pada kriteria baik.

Hasil analisis data angket respons siswa pada 22 siswa kelas VII-2 SMP Negeri 1 Meulaboh (subjek penelitian) menunjukkan dari setiap indikator menunjukkan bahwa: 1) Kemanfaatan dalam penggunaan media pembelajaran (kepuasan, minat, ketertarikan, keefektifan) dinilai baik dengan rata-rata persentase $88,9 \%$, 2) Kemudahan menggunakan media pembelajaran dinilai baik dengan persentase rata-rata $87,4 \%$. Hasil rata-rata dari seluruh indikator angket respons siswa pada uji coba subjek penelitian diperoleh sebesar $88,1 \%$, maka termasuk dalam kriteria baik, sehingga memenuhi aspek kepraktisan.

Hasil dari pemberian tes kepada subjek penelitian ditujukan untuk mengetahui aspek keefektifan media pembelajaran. Berdasarkan jawaban-jawaban siswa ditemukan kesalahan siswa dalam menjawab soal menyelesaikan operasi hitung dengan satuan sudut dalam menentukan nilai besar sudut dari suatu pukul jam yang ditentukan pada soal dan ditemukan juga sebagian siswa yang tidak membuat kesimpulan seperti apa yang diminta pada soal. Data yang diperoleh dari hasil tes kemampuan pemahaman yaitu terdapat 16 siswa yang nilainya memenuhi Kriteria Ketuntasan Minimum (tuntas) dan enam siswa yang nilainya tidak memenuhi Kriteria Ketuntasan Minimum (tidak tuntas). Hasil analisis data dari tes kemampuan pemahaman diperoleh persentase ketuntasan sebesar 72,7\% dan persentase ketidaktuntasan adalah 27,2\%. Dengan demikian diperoleh bahwa media pembelajaran yang dikembangkan peneliti dikatakan efektif penggunaannya dalam kegiatan pembelajaran. Hal ini sejalan dengan penelitian Hestuaji dkk (2013) yang menemukan bahwa hasil belajar siswa yang diberi perlakuan media kartu domino lebih baik daripada hasil belajar siswa yang diberi perlakuan media gambar diam. Hal ini terjadi dikarenakan media kartu domino memiliki kelebihan untuk membuat siswa lebih aktif semangat belajarnya dengan media pembelajarannya yang seperti permainan daripada media pembelajaran gambar diam yang masih bersifat monoton.

\section{PENUTUP}

Berdasarkan pemaparan-pemaparan di atas maka media pembelajaran kartu domino sudut yang dikembangkan peneliti layak untuk digunakan dalam pembelajaran matematika materi sudut di kelas VII SMP Negeri 1 Meulaboh, dengan aspek valid mendapat persentase $77,5 \%$ kategori baik, aspek kepraktisan media kartu domino mendapat $88,1 \%$ kategori baik, dan aspek keefektifan media yang dilihat dari tes pemahaman konsep siswa mendapat persentase $72,7 \%$ atau 16 dari 22 siswa tuntas. Media kartu domino dirancang dan dikembangkan berdasarkan penilaian para ahli dan uji coba lapangan. Kartu domino yang dilengkapi dengan gambar-gambar yang berkaitan dengan materi sudut mudah dipahami siswa serta nyata dalam kehidupan sehari-hari, hal ini membuat siswa kelas VII SMP Negeri 1 Meulaboh mudah memahami konsep-konsep materi sudut. Namun media yang akan dikembangkan perlu menyesuaikan dengan karakteristik siswa, karena setiap media memiliki kekhasan masing-masing untuk membantu guru dalam menjelaskan materi tertentu sehingga pemilihan tes, alat peraga, 


\section{Formatif: Jurnal Ilmiah Pendidikan MIPA}

Vol. 9, No. 2, Juni 2019, pp. 91-100

p-ISSN: 2088-351X

e-ISSN: 2502-5457

DOI: http://dx.doi.org/10.30998/formatif.v9i2.3089

dan lain-lain perlu dikembangkan berdasarkan kebutuhan dan permasalahan yang terjadi di kelas.

\section{DAFTAR PUSTAKA}

Astuti, D.P., Leonard, L., Bhakti, Y. B., \& Astuti, I. A. D. (2019). Developing Adobe Flash-based mathematics learning media for $7^{\text {th }}$-grade students of junior high school. Journal of Physics: Conf. Series 1188012098. http://dx.doi.org/10.1088/1742-6596/1188/1/012098

Barnawi \& Arifin, M. (2017). Microteaching: Teori \& Praktik Pengajaran yang Efektif dan Kreatif. Yogyakarta: Ar-Ruzz Media.

Budiono. (2018). Use of learning CD media to improve student motivation and mathematics learning outcomes. Formatif: Jurnal Ilmiah Pendidikan MIPA, 8 (2): 101-110. http://dx.doi.org/10.30998/formatif.v8i2.2459.

Handhika, J. (2012). Efektivitas media pembelajaran IM3 ditinjau dari motivasi belajar. Jurnal Pendidikan IPA Indonesia, 1 (2), 109-114.

Harsono, D. N. \& Prihatnani, E. (2018). Pengembangan permainan domat card pada materi sistem persamaan linier satu variabel. Maju: Jurnal Ilmiah Pendidikan Matematika, 5 (1): 1-13.

Hestuaji, Y., Suwarto, \& Riyadi. (2013). Pengaruh media kartu domino terhadap pemahaman konsep pecahan. Didaktika Dwija Indria, 3 (1): 1-6.

Nieveen, N. \& Plomp, T. (2007). An Introduction to Educational Design Research. Netherlands: Institute for Curriculum Development.

Prasetyo, M. F. \& Prihatnani, E. (2018). Pengembangan permainan monomath pada materi persamaan garis lurus bagi siswa kelas VIII SMP Negeri 10 Salatiga. Maju: Jurnal Ilmiah Pendidikan Matematika, 5 (1): 14-26.

Prihanto, D. A. \& Yunianta, T. N. H. (2018). Pengembangan media komik matematika pada materi pecahan untuk siswa kelas V Sekolah Dasar. Maju: Jurnal Ilmiah Pendidikan Matematika, 5 (1): 79-90.

Rahman, A. A. (2017). Pengembangan perangkat pembelajaran berbasis pendekatan realistik untuk meningkatkan kemampuan pemecahan masalah matematis siswa SMP N 3 Langsa. Maju: Jurnal Ilmiah Pendidikan Matematika, 4(1), 26-37.

Sagala, S. (2010). Konsep dan Makna Pembelajaran. Bandung: Alfabeta

Sanjaya, W. (2011). Strategi Pembelajaran Berorientasi Standar Proses Pendidikan. Jakarta: Kencana Prenada Media.

Supardi, Leonard, Suhendri, H., \& Rismurdiyati. (2012). Pengaruh media pembelajaran dan minat belajar terhadap hasil belajar fisika. Formatif: Jurnal Ilmiah Pendidikan MIPA, 2 (1): 71-81. http://dx.doi.org/10.30998/formatif.v2i1.86.

Sutiarso, S., Coesamin, E., \& Nurhanurawati. (2018). The effect of various media scaffolding on increasing understanding of students' geometry concept. Journal $\begin{array}{llll}\text { on } \quad \text { Mathematics } & \text { Eduction } & 9 & \text { (1): }\end{array}$ http://dx.doi.org/10.22342/jme.9.1.4291.95-102.

Wijayanti, R., Hasan, B., \& Loganathan, R.K. (2018). Media comic math berbasis whiteboard annimation dalam pelajaran matematika. Jurnal Riset Pendidikan Matematika, 5(1):53-63. http://dx.doi.org/10.21831/jrpm.v5i1.19207. 